\title{
Quality revolutions, solidarity networks, and sustainability innovations: following Fair Trade coffee from Nicaragua to California
}

\author{
Christopher M. Bacon ${ }^{1}$ \\ Santa Clara University, USA
}

This is the essence of a quality exchange-quality coffee for the buyers in exchange for a higher quality of life and environmental quality within producer communities.

Merling Preza, General Manager of PRODECOOP, a cooperative of small-scale coffee farmers in northern Nicaragua.

Like a potter who needs very fine clay for fine pottery, we need very fine coffee to survive against the huge corporations.

Paul Katzeff, CEO of Thanksgiving Coffee Roasting Company, a small-scale coffee company in northern California.

\section{Introduction}

Thousands of coffee growing communities entered a deep crisis between 1999 and 2004, when green coffee prices plummeted from US\$1.20/lb to US\$ 0.45/lb (US\$ 2.64/kilo to US\$ 0.99/kilo) (Bacon 2005). Discounted for inflation, these were among the lowest coffee prices on record. The effects in coffee-growing communities were immediate and severe. The United Nations' World Food Program declared a food security emergency in Central America coffee-growing regions (WFP 2003). Faced with dramatic economic losses, many Latin American farmers sacrificed the biodiversity associated with shade coffee when they switched to cattle ranching in search of better economic returns. In Nicaragua, banks foreclosed on about $10 \%$ of the coffee farms, and school attendance rates declined as families pulled children out of school to help in the fields (CEPAL 2002). Civil society development organizations, such as Oxfam International, ensured that the humanitarian crisis accompanying this coffee price crash received ample publicity, including a US Congressional Hearing in 2002, and multiple articles in mainstream newspapers.

The dominant response to the post 1999 coffee price crisis in Central America consisted of international and domestic government support for mitigation of economic losses and partial alleviation of humanitarian issues, without substantially altering existing agrarian power relations (Bacon et al. 2008a). This consisted of debt forgiveness for some of Central America's largest coffee farmers, increased food aid intended for rural workers (often channeled through the owners of these farms), and in some cases additional investment in rural infrastructure including roads and schools. Research and policy often promoted solutions through diversifying production away from coffee, or increasing the quality of the coffee and accessing price premiums in the specialty coffee market. These responses could be identified with mainstream corporate social responsibility. The conventional political economic analysis largely focused on the persistent NorthSouth inequalities within the coffee value chain (Talbot 2004), suggesting the need for increased state-based cooperation including a new binding international coffee agreement. But this provided few short-term steps to resolve the collapse of the sector.

Nicaraguan smallholder cooperative leaders working in partnership with a Californian small-scale roasting company CEO pioneered an alternative approach. They united to design and build coffee tasting laboratories among smallholder producer cooperatives, and then cooperative leaders used this opportunity to catalyze local organizing efforts and create a national smallholder cooperative association. This association soon gained a share of power in a domestic coffee industry historically dominated by colonial powers, and corporate and domestic elites. These cooperatives also stood at the forefront of the burgeoning Fair Trade movement.

This article concerns a flagship project within this alternative approach to confront the coffee crisis. The protagonists are several leaders of smallholder Fair Trade coffee cooperatives in Northern Nicaragua, including Merling Preza, Fatima Ismeal and Pedro Hasslam; and Paul Katzeff, CEO of Mendocino, California's Thanksgiving Coffee Company, who served as the project director. As a three-time president of

\footnotetext{
1 Dr. Christopher Bacon, Assistant Professor, Department of Environmental Studies and Sciences, Santa Clara University, CA 95050-4901, USA. cbacon "at" scu.edu. I acknowledge extensive editing by Colin Duncan, Ravi Rajan and Simon Batterbury as well as comments from several colleagues, especially at Nancy Peluso's Land Lab. This is the third paper in Rajan S.R. and Duncan C.A.M. (eds.) "Ecologies of Hope", special section of the Journal of Political Ecology 20: 70-179.
} 
the Specialty Coffee Association of America and longtime promoter of "high quality" artisan coffee, social justice and sustainability, Kazeff's life has much to teach us about the history, innovation and politics of coffee. The coffee quality improvement project he proposed in the 1990s combined a structural analysis of the coffee value chain structure, and commitments to social activism, with the industry-based knowledge of coffee roasting craftsmanship and a leadership role in the specialty coffee industry. The idea was to build coffee tasting laboratories embedded within smallholder Fair Trade cooperatives.

In this article, I present three interconnected sustainability innovations within this system, and reveal the social, political and ecological histories that made them possible (Seyfang and Smith 2007). Northern roasters, the importers, and a handful of inaccessible laboratories in coffee producing countries largely control the "secret" art of coffee tasting and quality identification. The first innovation was the diffusion of coffee quality control labs, essentially coffee tasting facilities and the associated quality control systems to sort beans by size and identify their physical defects. These were among the first labs that smallholder cooperatives constructed coffee growing regions. This innovation interconnected with a second one, when Nicaraguan smallholder cooperatives united to form a national association. Thirdly, the Fair Trade system of certified producer associations, importers, roasters and retailers, is an innovation that crosses from North to South.

If we take a step further back into the history embedded in Nicaragua's coffee landscapes and communities, we see the catalytic role of the 1979 Revolution and subsequent Sandinista agrarian reform in supporting cooperatives and inspiring the international solidarity networks that are intimately connected to short-term success of a coffee quality project, and the emergence of Fair Trade coffee in North America. These deeper histories reveal several of the important causal roots associated with three recent sustainability innovations. They also contribute to re-inserting their politics at a moment when some certification agencies have led a race into mainstream and shallow corporate social responsibility, which risks depoliticizing and redefining Fair Trade to meet their market-based goals.

The article starts out by comparing the mainstream and alternative approaches to the coffee crisis. Next, it delves into a case study of a coffee quality improvement project that linked a roaster with ten Fair Trade smallholder cooperatives in northern Nicaragua, reporting briefly on the results of field research conducted across coffee producers in the mid 2000s. The final section discusses resonances with other articles in this Section and emergent theoretical considerations.

\section{The coffee crisis: conventional vs. alternative responses}

Although nominal prices paid to coffee producers have rebounded slightly since 2004, the impacts of the crash remain, compounded by pre-existing chronic poverty. In other words, even though prices have recovered, the coffee crisis for many producer communities continues (Renard 2010). Figure 1 compares the real conventional market prices with the minimum price floor established for Fair Trade certified coffee. Using the USA Consumer Price index to discount the prices for inflation, it shows the importance of the Fair Trade floor when conventional prices plummet, and discloses the declining real value of the Fair Trade price. When discounted for inflation, real coffee prices have declined substantially, losing more than $66 \%$ of their value from 1980 to 2005 (Lines 2005: 181). The binding economic clauses of the International Commodity Agreements (ICA) lasted from 1962 to 1989 and controlled world coffee prices. The agreement was supported by the US, the major consumer, as a compromise to guarantee supply (Gilbert 2011: 15). The coffee ICA served to slow the rate at which the coffee commodity prices lost their real value (Talbot 2004; Gilbert 2011). The ICA disintegrated due to a combination of changing geopolitics (i.e. the fall of the USSR), the triumph of a market-centric approach to trade and development, and to a lesser extent the accumulation of internal problems within the ICA system (e.g. larger corrupt bureaucracies, countries not following their import/export quotas, and inefficient capacity within domestic government agencies).

The conventional price crisis overwhelmed vulnerable rural economies and threatened the biodiversity associated with traditional shade coffee production, as farmers searched for more viable land use activities. From 1999-2002, the total monetary value of Central American coffee exports declined from US\$1,678 billion to US\$ 700 million (IADP et al. 2002). These low prices also increased debt burdens and provoked bankruptcies among coffee exporters, millers and farmers in producing countries. An estimated $10-20 \%$ of Nicaragua's coffee farmers lost their land during the crisis, and laborers lost over 4.5 million work days (CEPAL 2002). The large plantation owners stopped paying the rural landless coffee workers employed in their operations. 


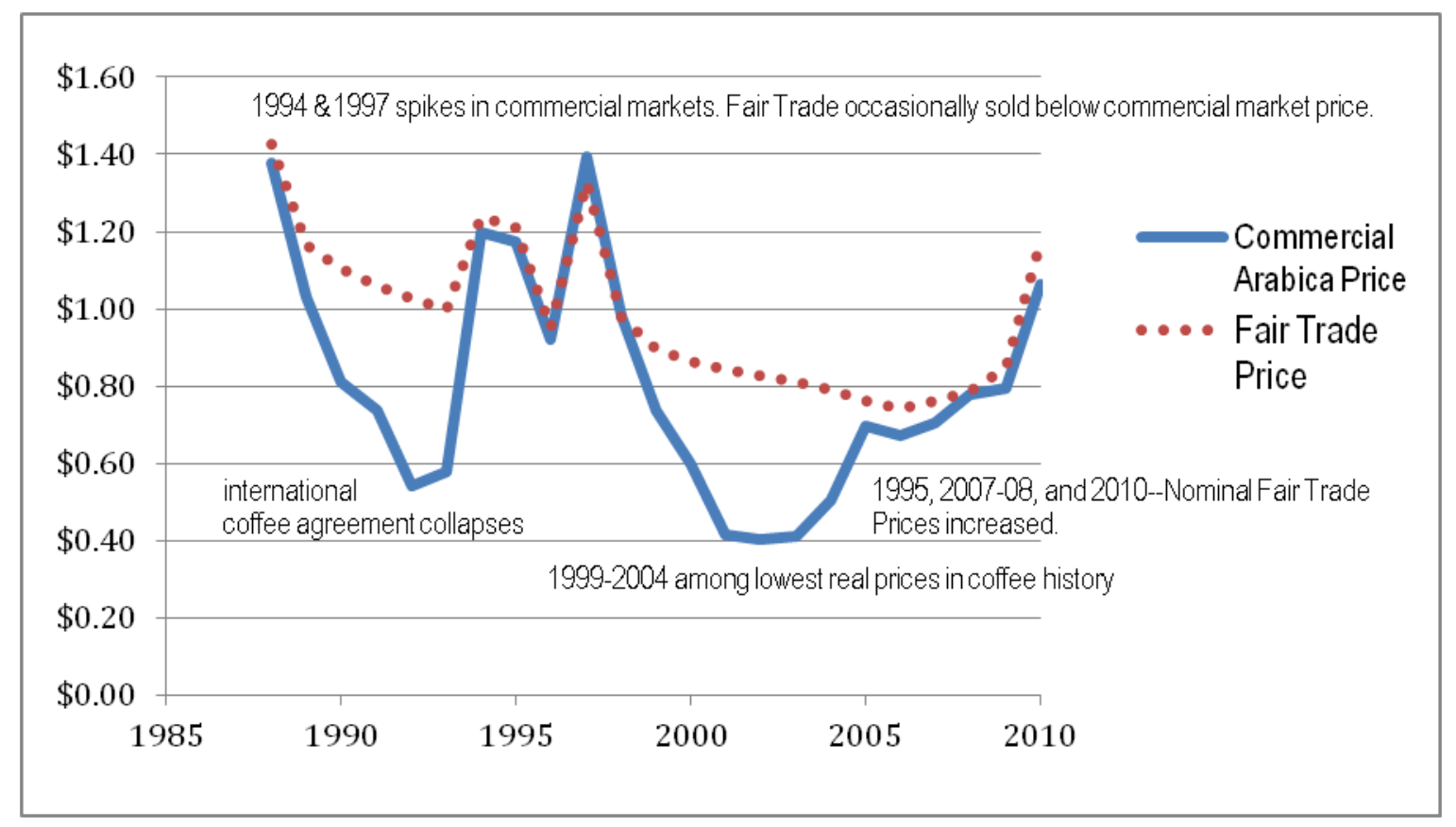

Figure 1: Real Fair Trade vs. commercial coffee prices 1988-2010 (using 1988 US\$/lb green arabica coffee as the base year). Source: Modified from Bacon 2010a.

\section{The Neoliberal responses to the crisis}

The conventional Neoliberal response to the coffee crisis comprised the actions of governments, multi-lateral development banks and large-scale corporations. In a document titled Managing the competitive transition of the coffee sector in Central America, the Inter American Development Bank, United States Agency for International Development, and the World Bank provided a private sector based roadmap for increasing coffee quality and marketing efforts (IADB et al. 2002). An important, though unstated, component of this strategy was to implement these projects nominally intended for smallholders while maintaining profits levels for the US based coffee industry and in ways that did not significantly change the dominant political economic structure of the Central American coffee sector. The coffee production structure consists of strong transnational corporate control of exports and increasingly, coupled with changing familybased oligarchies that are often control (sometimes with transnational capital investments) coffee exporters and own the largest coffee plantations (Paige 1997). This is partially evidenced by uneven land distribution. For example, in Guatemala less than $3 \%$ of the farms control more than $70 \%$ of the coffee land, and these patterns are closer to 50\% elsewhere in Central America (CEPAL 2002).

This "conventional" strategy focused on improving coffee quality, efficiency, traceability, and marketing to the expanding North American specialty industry. The international grant and loan funds were channeled primarily through transnational commodities trading companies and international NGOs, and in the end, the funds often supported larger-scale centralized physical infrastructure for coffee processing and export. Although the US Congress committees that approved this funding specifically mentioned benefits for small and medium sized farms, significant portions of the aid money ultimately benefited large landholders and private exporters. When the donor agencies considered sustainable coffee certifications, they generally opted for those with lower ecological standards than organic coffee, and with social justice requirements less stringent than those used for Fair Trade certified products, since other certifications, such as Rainforest Alliance, were cheaper and posed fewer changes to industry practice. These agencies were less involved in the conventional strategy's third component, which provided more than US\$100 million as an economic bailout for the highly indebted large landholders and private export houses (Bacon 2006).

The conventional neoliberal solutions were consistent with previous structural adjustments such as the privatization of state run coffee agencies, and the roll-back of market regulation. These strategies included selling to the more lucrative specialty coffee market segment, purchasing risk management insurance to mitigate coffee price variability (insufficient for dealing with a dramatic price crash), internet connections so farmers could see coffee prices on the open market, and promoting coffee quality improvement programs to 
increase their export to higher paying markets (World Bank 2005; IADB et al. 2002). The "other" producers - those who ostensibly could not make the quality cut - were subject to the "creative destruction of the market" and were expected to diversify into other export-oriented cash crops (CATO 2003).

The coffee crisis initially challenged neoliberal approaches to international development, since it brought about the de-regulation of the coffee market (e.g. the fall of the ICAs), the privatization of domestic coffee support agencies, and consequently, the elimination of a rural social safety net (for health, housing and education). Media coverage of the social and environmental consequences often laid some of the blame squarely upon the massive corporation, that dominated the coffee trade and roasting industry, including Nestlé and Phillip Morris. Oxfam International led an effective campaign that simultaneously highlighted the humanitarian crisis and connected them with the structural causes related to declining real prices paid to producers and the "rigged rules and double standards" that powerful Northern countries and corporations imposed upon Southern producers (Watkins and Fowler 2002). Unfortunately, most of these debates were left unfinished after charitable foundations reduced their funding for commodity and development related policy work and Oxfam decided to substantially cut funding to its Fair Trade and coffee campaign around 2007.

\section{The emergence of alternatives}

In the same way that alternative agri-food systems proliferated in response to the consequences of an industrial agrifood system (Allen 2004), the well-publicized dystopias unleashed by the coffee crisis provided fertile ground for expanding several alternative approaches. The collective international answer to this coffee crisis included NGOs, forward thinking coffee companies, and selected coffee producer cooperatives spearheading efforts to create 'relationship coffees' and enter into sustainability certification programs within the expanding specialty coffee industry. This effort coincided with growing consumer awareness and demand for higher quality and more sustainable foods and beverages (Goodman 2000). In the coffee sector, the rise of specialty coffee, enterprising certification agencies, and sustainable food advocacy converged to spread several eco-labels including organic, bird-friendly, Rainforest Alliance and Fair Trade certified. Among this rapidly expanding constellation of sustainable coffee partnerships, many development and social movementoriented civil society organizations have identified Fair Trade and organic coffee networks as two of the alternative approaches that have the most promising sustainability and development outcomes (Bacon et. al 2008a; Raynolds et al. 2007; Jaffee 2007).

Fair Trade and organic practices emerged from social movements that saw themselves as functioning outside mainstream commodity markets (Brown 1993; Bacon et al. 2008a; Jaffee 2007). After the development of certification programs, both eco-labels rapidly expanded through their engagement with a set of progressive roasters and retailers within the specialty coffee industry, and more recently with a host of mainstream corporations. According to the largest Fair Trade association;

Fair Trade is a trading partnership, based on dialogue, transparency and respect, which seeks greater equity in international trade. It contributes to sustainable development. Fair Trade organizations (backed by consumers) are engaged actively in supporting producers, awareness raising and in campaigning for changes in the rules and practice of conventional international trade (Krier 2005).

Although several certified Fair Trade products now include large landholders, the international Fair Trade coffee and cacao standards require trade with smallholder cooperatives (FLO 2007). In practice, Fair Trade is an uneven and often contradictory combination of different relationships connecting producers to consumers through diverse enterprises oriented toward different visions of the relationship between economy and society (Polanyi 1944). These range from corporate social responsibility approaches that require minor changes and generally enable 'business as usual' - for existing firms in the industry, to those actively seeking to create a more democratic economy organized into cooperatives, and to the many hybrids the fall along this continuum (Bacon 2010a).

Instead of silencing the post 1999 coffee crisis debates - a position taken by conventional coffee industry - the Specialty Coffee Association of America (SCAA) hosted lively discussions. Several smallscale coffee roasting companies united to create the SCAA in 1982. They saw themselves as a radical break from the mainstream market and a place for progressive politics, craftsmanship and higher margins (Katzeff 2001a). As of 2008, the SCAA's 2600+ members consisted primarily of small-scale roasting companies, but also include traders, and larger companies such as Starbucks, farmer organizations, and producer-country representatives. The SCAA sought to differentiate itself from the US\$ 80 billion bulk conventional coffee market by promoting coffee quality and sustainability. Despite the inherent subjectivity of taste, it is a fact that quality standards, including both the number of physical defects on the bean and especially the flavors in the cup, are the primary criteria that most roasters and importers use when deciding which coffees to buy and how much to pay. The North American specialty coffee market grows annually by 5-10\%, reaching an estimated retail value of US\$ 11 billion by 2005 (Liu 2007). 


\section{The political ecology of alternative food networks}

Instead of blaming the victims and suggesting coffee farmers submit themselves to the "creative destruction" of markets and look for another export crop, political ecologists elucidate issue of power within the value chain and highlight the structural and historical causes associated with local outcomes. As Goodman notes, "By wide consensus, the origins of the present crisis are to be found in the breakdown of the International Coffee agreement (ICA) in 1989, the ensuing relaxation of supply controls, and the cumulative weight of chronic over-production on 'green' coffee prices in world export markets" (Goodman 2008: 5). Pronounced structural shifts, including corporate consolidation, have occurred in the coffee value chain in favor of Northern roasters and retailers (Talbot 2004). In the past 15 years, coffee producers' export earnings have fallen from US\$ 10-12 billion to less than US\$ 5.5 billion, whereas international coffee market revenues have risen from US\$ 30 billion to over US\$ 70 billion. In short, the share of producing countries in the coffee value chain has fallen from 30\% to less than eight percent (Ponte 2004; Talbot 2004). On the other hand, it was this same International Coffee Agreement mediated by Southern states that failed to provide market access to the Mayan small-scale coffee farmers that led them and their allies to begin creating an alternative Fair Trade agro-food system (Vanderhoff 2009).

The rise of the specialty coffee industry and certification led several scholars to ask "Who gains from product rents as the coffee market becomes more differentiated?" (Fitter and Kaplinsky 2001). As in the commodity chain literature (Bair 2009), a Global Value Chain (GVC) analysis considers the international structure of production, trade, and consumption of commodities as disaggregated into stages that are embedded in a network of activities controlled by firms (Daviron and Ponte 2005). The term 'global coffee value chain' refers to the world-wide industry, whereas specific reference to the Nicaragua-USA coffee value chain or the 'Fair Trade value chain' refer to the smaller subset of place-specific relationships within this larger system.

What is quality and how does it create value? Daviron and Ponte propose three categories for understanding quality and its links to economic value: product quality (i.e. size, physical defects, color and taste), symbolic quality (trademarks, brands, and certifications) and in-person service quality (for example, the way the barista makes and serves your latte) (Daviron and Ponte 2005). Together with an analysis of the uneven power dynamics in the value chain, these concepts are used to unpack the relationships connecting value added, standards and price. The findings show farmers connected to a Fair Trade and organic value chain that can add both product and symbolic qualities and receive higher prices, though not always a higher percentage of the final retail price (Daviron and Ponte 2005; Bacon, Mendez, Gliessman, Goodman, and Fox 2008). Figure 2 compares the Fair Trade and conventional value chains, and illustrates the integration that occurred in Nicaragua when smallholder cooperatives built cupping labs and used Fair Trade market access to scale-up in the value chain.

Rural sociologists and political ecologists were the first agro-food analysts to study the rapid rise in "alternative" agro-food systems (Goodman and Watts 1997). Several initial studies were cautiously optimistic about these potentially "more sustainable" foods and beverages. For example, Whatmore and Thorne published an article in 1997 analyzing the diverse networks that moved Fair Trade coffee from small-scale producers in Peru to more conscious consumers in the UK (Whatmore and Throne 1997). Marie-Christine Renard's pioneering book about the intersection of bottom up peasant organizing efforts in Mexico and the development of the Fair Trade coffee certification system showed cautious optimism about the effects of these trade relationships (1999). In both Nicaragua and Mexico, our own findings have shown that although livelihood insecurities persist, households connected to a Fair Trade market were less vulnerable to the consequences of crashing coffee commodity prices (Bacon 2005a; Mendez et al. 2010). Tad Mutersbaugh also recognized the potential benefits of certification programs, but highlighted the contradictions through detailed ethnographic studies analyzing how the use of local farmers in organic coffee inspection systems and requirements can disrupt indigenous labor routines and complicate neighborly relationships within several communities in Oaxaca, Mexico (Mutersbaugh 2004).

The alternative value chain is characterized by more interaction and communication among buyers, producers, cooperative managers, and farmers and could contribution to accelerating grassroots sustainability innovations (Seyfang and Smith 2007). Innovation has traditionally referred to the introduction of a new dimension of performance. This "new" dimension can emerge from a product, a different form of social organization, or it can be embedded within systems of production, distribution, and consumption. I am interested in innovations that could enable community level empowerment, equity and more sustainability livelihoods. There is a vital role in highlighting systematic traps and shortcomings associated with the corporatization of proposed alternatives (Guthman 2007), uncovering histories of violence and displacement (Peluso and Watts 2001), and identifying avenues for policy change (Bebbington 2000). If this research is connected to participatory research processes with and for communities and social movements, there is a strand of political ecology that can contribute to opening ecological imaginations and creating possibilities through collective action and sustainability innovations (Watts and Peet 2004; Rocheleau 2008). 


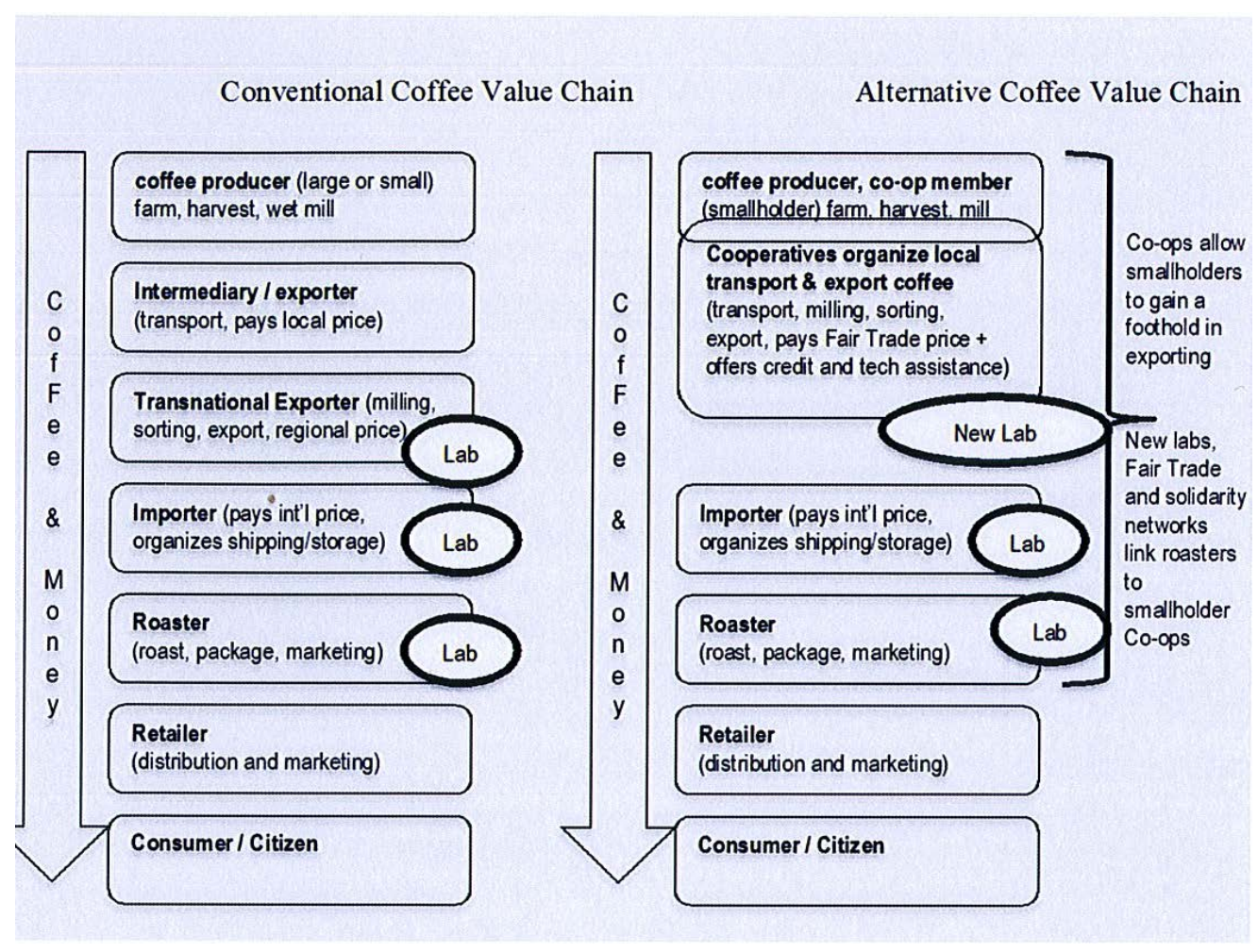

Figure 2: The conventional and alternative coffee value chains in Nicaragua.

\section{Two revolutions, international solidarity, and innovations}

In order to explore the political ecology of the conventional and alternative coffee value chain this case study follows the bean from Nicaragua's northern mountains to northern California's coastal cities. Beyond tracking the physical coffee bean from mountainside family farmers into the hands of Bay Area coffee drinkers, our story recovers the historic processes, and touches upon the international solidarity networks, that enabled sustainability innovations within the coffee value chain. ${ }^{2}$ This story occurs from 1999 through 2008, yet the agrarian reforms and collective social relationships that enabled the sustainability innovations trace their history to Nicaragua's revolution in 1979.

\section{Nicaragua's popular revolution}

After more than 45 years of the Somoza family dictatorship and their personal wealth accumulation, the Nicaraguan people rose up and toppled them, taking over the capital city of Managua on July 19th, 1979 (Ramírez 1999). By the late 1970s, the Somoza dynasty had controlled more than $25 \%$ of all productive assets in the country (Austin, Fox and Kruger 1985). There was frequent state-backed torture, and political oppression (e.g. no free elections, effective opposition parties, or a free press). The Frente Sandinista de Liberación Nacional, or the Sandinistas, led the collective uprising, which consisted of a broad based coalition involving several political parties, students, selected elites, indigenous communities and rural families (Saldaña-Portillo 2003). This bottom-up support emerged from organizing efforts conducted throughout the 1970s, and a political platform that responded to their aspirations and interests (Gould 1990). After initially setting up a multiparty governing council, the Sandinistas consolidated their power and the executive branch named Daniel Ortega the President.

With broad based popular support from most Nicaraguans in the early 1980s, solidarity from many countries, and a little room to maneuver after the US pulled its support for Somoza (and before it started using "secret" military bases in Honduras to finance, arm and directly attack targets in Nicaraguan territory), the early political leaders began the task of remaking the government. They amended important components

\footnotetext{
${ }^{2}$ A transnational solidarity movement is a series of social network connections in which protagonists in two or more countries coordinate efforts to achieve a common political purpose (Perla 2008: 138).
} 
of the Constitution to expand civil, political and social rights; created a new army oriented toward public protection and a new police force, while simultaneously making commitments to free public education, conducting a highly effective national literacy campaign, establishing innovative community-based public health programs, and implementing agrarian reforms. The early years were characterized by many stories of social change and transformation as artists, politicians and individuals sought re-make Nicaraguan society (Cardenal 2003; Belli 1984).

Government agrarian reforms led by the Sandinistas planted the organizational seeds for Nicaragua's agricultural modern smallholder cooperative sector and its connections into Fair Trade networks (Enríquez 1991). The government managed a series of land reforms throughout the 1980s, which eventually affected up to $50 \%$ of the 5.6 million hectares then in production (CIPRES 2006). The first phases of the land reform had broad public support since they primarily consisted of reallocating Somoza's vast assets. Most-but not all —of this land was redistributed from large holdings into state run enterprises and thousands of cooperatives (CIERA 1989). Influence remained with the top-level government agencies from the 1980s into the early $21^{\text {st }}$ century. This was due in part to a Sandinista strategy pursued from the mid-1980s. They gradually lost connection with the aspirations of a growing number of smallholders and workers. So they simultaneously provided avenues for smallholder collective organizing and agency, while frequently reserving the balance of political power for the large landholders and party leaders (Holt-Giminez 2006: 185).

Although the Sandinista government made economic blunders (e.g. skyrocketing inflation and contradictory agricultural policies), permitted internal corruption, and was arguably misled by an ideological domestic politics that failed to "recognize that autonomous forms of class, ethnic, and regional consciousness can aid rather than impede the development of the revolutionary process" (Gould 1990: 67), the reason why the government did not fully deliver upon its potential, or win the 1990 election, can be explained primarily by the US backed Contra War. The USA's military intervention overwhelmed the Sandinista government's capacity to simultaneously re-build a country and fight a Superpower. The US backed insurgency started when the ex-members of Somoza's elite and notoriously brutal military guard, La Guardia, fled to Honduras. From this territorial base, the US military and CIA provided them with arms, training, and logistical support. After initially considering Scandinavian social democratic style economic policy, powerful and ideologically motivated leaders in the Sandinista turned increasingly to Cuba, Libya and the former USSR among others for support. These alliances only exacerbated the heat within this Cold War conflict, and with a few exceptions delivered few benefits to Nicaraguans. By the mid-1980s, the Contras were able to recruit an increasing number of disaffected and hungry Nicaraguans, both voluntarily and forcefully. In a country with population of less than four million at the time, more than 50,000 Nicaraguans were killed in the war, affecting everybody living in the country (Kinzer 1991).

The Contra War became an ideological project for President Reagan and several members of his Administration. Citing fears about the spread of Communism from Cuba to Nicaragua and then beyond, and the Sandinista's increasing tilt towards Russia, Reagan considered the Contras "Freedom Fighters" and ensured that they would be armed, financed, and provided direct military support at times in violation of Congressional laws and over the objections of most US citizens. The Central American Peace and Solidarity Movement catalyzed much of the North American based civil society resistance by organizing thousands of international delegations, cultural events, and media campaigns. The San Francisco Bay Area (henceforth, "Bay Area") emerged as an important hub for these solidarity-based organizing efforts.

After the Sandinista party lost the elections in 1990, government subsidies stopped flowing to smallholder cooperatives and moved toward the large private landholders. In the 1980s, coffee cooperatives were often run by national government agencies in a top-down fashion, and few producer organizations had direct access to importers and roasters, nor were the cooperatives able to re-invest the revenues from their coffee sales into their business and community development projects (Chamorro 2005). The Sandinista government's agricultural Ministry only began titling land to individual smallholders in the late 1980s. The agrarian reform cooperatives that survived the political changes into the 1990s were generally the ones that affiliated with larger cooperative unions and most of them eventually connected into the Fair Trade system. The most effective cooperatives that continue to lead a resurgence of the Nicaragua cooperative movement in the early $21^{\text {st }}$ century consisted of smallholder coffee growers, many of which are now connected to Fair Trade markets and the specialty coffee industry.

\section{The roots of the specialty coffee revolution in California and the US}

In a related series of events, Northern California became an epicenter for the birth and growth of the specialty coffee industry, including pioneer specialty coffee roasters like Peets Coffee in Berkeley, and Thanksgiving Coffee in Fort Bragg. This industry was small throughout the 1980s before the rapid expansion of Starbucks and Peets Coffee brought it into the mainstream by the late 1990s. In fact, Starbucks' first roastmaster was hired away from Peet's coffee. The San Francisco Bay Area was an important node for both the specialty coffee industry and the Central American Peace and Solidarity Movement (CAPSM). Many international solidarity delegations, led by organizations like Witness for Peace, traveled to Nicaragua, and picked coffee in war zones (Burbach 2009). These experiences changed the perspectives and awakened the 
political consciousness among thousands of people that later returned to their Western countries to become academics, business leaders and politicians. They often returned home with several bags of terrible tasting coffee (product quality was not an issue among those interested in politics at the time) and attempted to sell solidarity-based coffee to their friends, church congregations, and political allies. Others would go on to build businesses and certification agencies (e.g. Paul Rice, CEO of TransFair USA).

Some people, like Paul Katzeff, would dramatically influence the structure of the coffee industry. Originally from New York, Paul Katzeff is a self-described 1960s radical who claims to have once run Hunter S. Thompson's campaign for Sheriff in Aspen, Colorado, before moving to Northern California to found one of the earlier artisan coffee roasting companies in 1972. Katzeff's life and work tell the story that connects the Central American Peace and Solidarity Movement with sustainability innovations, and Fair Trade coffee more than anybody else. After studying agronomy at Cornell University and later employment as a social worker, he returned to New York City to work in his father's grocery store. He also became active in tenant housing organizing efforts. The combination of a broken heart, Beatnik poets and the ocean were enough to inspire Katzeff's continued Westward migration. He eventually moved to Mendocino, California, co-founded Thanksgiving Coffee Company (TCC) with Joan Katzeff and spent plenty of time in the Bay Area.

Coffee and revolutionary politics overlapped in unexpected places. Together with several small-scale roasting companies and importers, many of which were based in the Bay Area, Katzeff became a co-founder of the Specialty Coffee Association of America (SCAA). The SCAA would later become the world's largest (by number of members) coffee industry association. Their third annual meeting in February 1985 included a symposium entitled "Coffee, Human Rights and Third World Economies" (TCC 1987). Apparently during this symposium an activist filled a nearby water fountain with red dye, dramatically demonstrating the blood coffee from El Salvador that roasting companies purchased from the same landed elite that controlled the large coffee plantations and also financed the death squads repressing popular resistance. Katzeff, who was an early president of the association, promoted a open dialogue that took issues of human rights and environmental sustainability more seriously than most industry associations. Nicaragua's Sandinista government sent Daniel Nuñez, the president of the national farmers and ranchers' association and arguably the country's most powerful peasant leader in the 1980s, to attend the SCAA. Nuñez extended an open invitation to all participants to visit Nicaragua. Although Equal Exchange co-founder Jonathan Rosenthal also made many trips to Nicaragua in the 1980s, Kazteff claims to be the one who respond directly Nunez's invitation. Fair Trade coffee in the USA historically connected to coffee farming, smallholder cooperatives, and to Nicaragua's Sandinista Revolution.

Since that first trip in 1984, Katzeff has returned to Nicaragua on over sixty occasions (Katzeff, personal communication). The first coffee related project to emerge from these cross cultural exchange was called Coffee for Peace. The Reagan Administration declared an embargo on all Nicaraguan products in May of 1985. Thanksgiving Coffee Company then partnered with Oxfam Canada/Bridgehead Trading to import and roast the Nicaraguan coffee in Canada, and then import it again into the USA as a Canadian product. The coffee was then sold to individuals and groups active in the CAPSM as "Nicaraguan Coffee for Peace" (see Figure 3). Bridgehead trading in Ottawa paid ECAFE (the state-owned Nicaraguan coffee company that controlled nearly all exports during the 1980s) and then sent US\$ 1.54 for every pound of coffee directly to la Union Nacional de Agricultura y Ganederos (UNAG the national farmers and ranchers association, which was involved in creating rural producers' cooperatives throughout the 1980s and 1990s). The coffee was then sold to Canterbury Coffee in British Colombia and then imported by Thanksgiving Coffee as a finished product from Canada. Once the coffee was packaged and sold an additional US\$ 0.15/lb (US\$ $0.33 / \mathrm{kg}$ ) of roasted coffee was channeled directly to UNAG. There were several projects like this, including the dynamic work of Equal Exchange, a worker-owned cooperative and pioneering fair trade company created in Boston in 1986.

\section{The coffee quality revolution in Nicaragua, 1998-2004}

In 1998, Paul Katzeff returned to Nicaragua. However, this time he was not invited by representatives from the Sandinista government, but by the organizers of a shade-grown coffee conference in Managua. After his talk, a staffer from the United States Agency for International Development (USAID) asked him to submit a project. The core ideas for this project were summarized in a "Proposal to create a pilot project in Nicaragua, 1999-2002" (Katzeff 1998).

Katzeff's analysis identified the major institution in the part of the value chain controlled by producing countries as the dry beneficio. Farmers harvest de-pulp and wash this coffee before bringing them to these centralized processing plants where it is dried, sorted and packed in $152 \mathrm{lb}$ (69 kg) burlap sacks for export. The dry beneficios are largely in the hands of the agro-industrialists who often buy the small-scale farmer's coffee. The value chain structure leaves these farmers without access to their own coffee as a finished product-and thus the campesino has never tasted the fruits of his or her labor. So small-scale farmers sold an unknown product, to an unknown market, whose quality was graded according unknown standards, and received an unpredictable final price. Most farmers had no idea of the final retail prices paid for the coffee they grew. The goal of the project was break these blinders by building ten coffee tasting laboratories with 
small-scale farmer cooperatives. Katzeff's vision was that building labs with small-scale producer cooperatives would enable farmers to taste their own coffee as a finished product, improve coffee quality, invite premium-paying specialty coffee buyer into their spaces, and that the higher prices would encourage sustainable farm management and "eliminate" poverty (Katzeff 1998). Several of these cooperatives had already used Fair Trade as an important strategy to unite their cooperatives, and moved up in the value chain by purchasing their own agro-industrial facilities to prepare coffee for export. The importance of coffee tasting facilities in the value chain is explored below.

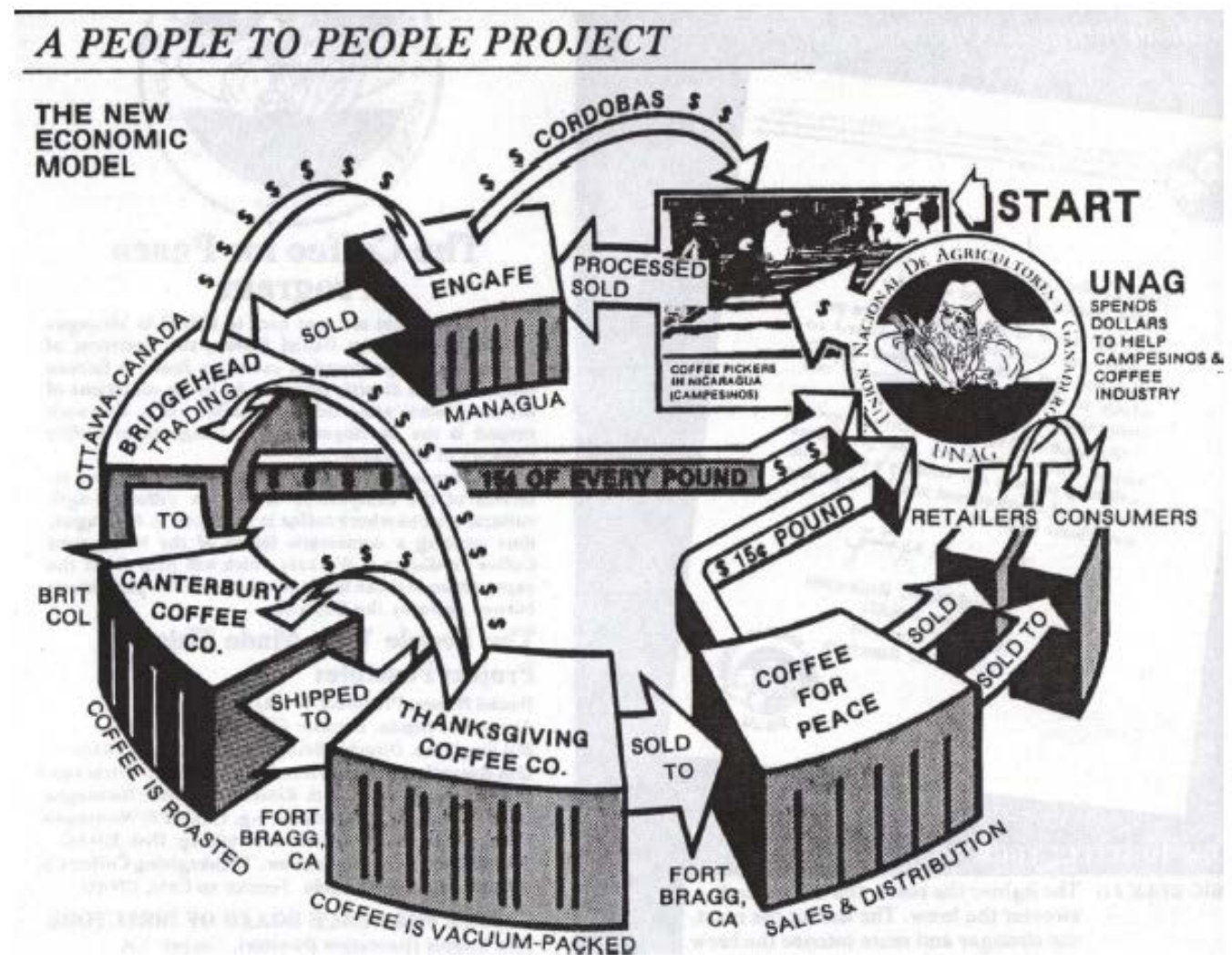

Figure 3: Coffee for Peace: a strategy to break the Reagan administration's embargo against Nicaragua. Source: Thanksgiving Coffee Company.

After successfully avoiding elite project capture, the next step was to find "authentic" smallholder cooperatives interested in building coffee tasting labs. This was much easier said than done. At the time, Nicaragua still had many cooperatives that actually consisted of larger landholders and a national association of exporters and landholders that had enjoyed decades of support intended for smallholders. In short, the Nicaraguan coffee industry was still squarely in the hands of the elite. The coffee labs project became high profile, with many organizations seeking entry. Nicaragua's three most important Fair Trade cooperative unions, PRODECOOP, SOPPEXCCA and CECOCAFEN were not involved at that time, and quite suspicious due to the USAID funding and the Nicaraguan field coordinator. But Nick Hoskyns, a Sandinista Revolution inspired Brit that moved to Nicaragua just out of college in 1989, knew the presidents and general managers of these cooperatives from his previous Fair Trade and solidarity work.

The project started with the cooperative presidents and general managers sharing a five-day vision trip to experience cupping labs in the US at Bay Area coffee importers, such as Holland Coffee and Royal Coffee, and roasters including Thanksgiving Coffee Company in Fort Bragg California. Most had never seen their coffee as a final product on the supermarket shelves, much less been inside the coffee cupping laboratories to see the people who make "the market" actually evaluate their coffee. In addition to gaining an insider's knowledge of the other end of this commodity chain, five days driving around California in a van provided a powerful trust-building and communications experience among the leaders from these cooperatives, several of whom had not previously worked together. The leaders returned to Nicaragua with the goal of designing smallholder cooperative-based coffee cupping labs. 
Visits to the cupping labs managed by some of the coffee industry's powerful buyers and importers further convinced the Nicaraguans that coffee slurping and mysterious discussion about detecting chocolate, citrus, blueberries, and apricots in their coffee mattered, and was potentially a core strategic investment. The art and science of coffee tasting, or cupping, has long been an esoteric practice conducted behind closed doors in small corporate "laboratories". Commercial roasters, importers and roasters are more interested in identifying and eliminating "defective" coffee beans (e.g. that have been over fermented, or are too old, or molded during storage), than finding those unique flavors in the cup. These defects are relatively easily identified either physically by the shape, size and color of the bean or by sour flavors and bad taste. However, specialty roasters were seeking specific flavor profiles that they could use in the proprietary blends that define their branded coffees. Although there was some basic defect elimination-based quality control plans in place in Nicaragua, no smallholder cooperatives had a cupping lab or the professional staff to taste the coffee and communicate with international buyers. Without this, there was little possibility of experimentation to improve quality, and no direct communication with the specialty roasters interested in differentiating Nicaraguan coffee on the international commodities market. Katzeff introduced a score sheet that cuppers could use to evaluate each coffee, suggesting that specialty coffees have scores of 80 and above on a scale of 1 to 100 (Figure 4). The sheet was later modified and adopted for general use by all SCAA members. This sheet is complemented by the SCAA's official coffee flavor wheel, including more than 60 distinct flavors, ranging from sour, astringent and scorched to leather-like and rounded.

Coffee tasting is a skill that is learned. The cooperatives invested in training a new cadre of young people to staff these labs and also work with farmers to improve their coffee quality. The criteria for selecting these cuppers included youthful enthusiasm, education beyond $6^{\text {th }}$ grade and, if possible, to be a child of one of the cooperative's coffee farmers. As of 2008, there were at least 20 new jobs created for young cooperative youth to continue their involvement in this coffee quality improvement project. These young cuppers proved to be effective coffee tasters and several have won international acclaim.

People working in different places established coffee cupping labs, developed quality control and assurance systems within the cooperative controlled segments of the value chain and scaled up in at least three ways. First - and most importantly - the participating cooperatives used the project as a platform to develop their own agenda. During our meetings with them from 2002 to 2004, PRODECOOP, CECOCAFEN, SOPPEXCCA and five other cooperatives united to create La Asociación de Cooperativas de Pequeños Productores de Café de Nicaragua, (The Nicaraguan Association of Smallholder Coffee Cooperatives) or CAFENICA. This association became the largest association of coffee farmers in Nicaragua representing more than 9,000 small-scale farmers, $80 \%$ of the Fair Trade coffee and more than $80 \%$ of the organic producers in the country. CAFENICA's national coverage (Figure 5) and administrative capacity enabled them to compete with the Associacion de Cafés Especiales, which was Nicaragua's dominant coffee association that primarily represents the interests of the landed elite and private exporters.

These efforts to scale up for political empowerment were matched with an economic approach that focused on a marketing strategy to expand their sales of specialty and certified "sustainable" coffee. Katzeff contributed to this goal by inviting the coffee importer from a larger-scale transnational trader on a tour, together with six owners/buyers from geographically separated regional specialty roasting companies across the United States. For ten days they toured the coffee cooperatives, cupped coffee in the labs, and built relationships. The coffee samples tasted, landscapes experienced, and personal relationships developed during this trip would later yield millions of dollars in annual coffee sales and more direct relationships with Nicaragua's cooperative sector.

\section{What were the outcomes?}

An agrarian power shift begins: The cooperatives were able to use their cupping labs, specialty coffee industry allies, and their intense bottom-up organizing effort, to create La Asociación de Cooperativas de Pequeños Productores de Café de Nicaragua (CAFENICA), and by 2009, to gain control of about 30\% of Nicaragua's coffee exporters. This was a dramatic structural change after more than 150 years in which foreign and local elites had dominated the domestic coffee industry. CAFENICA is the first autonomous smallholder coffee cooperative association in Nicaragua and among the strongest in Latin America. The Association's presence, together with support from the progressive specialty coffee roasters, Fair Trade certification, and a strong network of international NGOs supporting them, has effectively challenged the centuries-old dominance of the landed coffee elite as smallholder organizations compete successfully for rural development money and access to coffee buyers.

The members of CAFENICA have used their deeper knowledge about the qualities of their coffee as well as this political influence to ensure transparent conduct during the 2004 Nicaraguan Cup of Excellence competition (Table 1). The Cup of Excellence project team coordinates with specialty coffee roasters and importers from the US, Europe and Japan as it seeks to identify and promote the top quality coffees in different countries. These competitions are coordinated by a US based company, and occur in coffee producing countries. Farmers and exporters send their samples to a centralized warehouse, which is usually administered by an international NGO and/or domestic coffee association. The samples are coded so that the coffee tasters judge anonymous samples in a blind review process in the cupping labs. The number of coffee 
samples submitted to the competition in Nicaragua often exceeds three hundred (Tea and Coffee 2004). The top scores are announced and then sold at an international auction. Some lots of coffee earn prices that are four to ten times above the conventional commodity prices and gain an international reputation that could earn premiums for years (Wilson et al. 2012). In 2004, the international jury of coffee roasters awarded the coffee samples that originated on farms from CAFENICA-affiliated cooperatives nine of the top 11 prizes and 14 of the top 29 samples identified as finalists (see Table 1). PRODECOOP-affiliated cooperatives and farmers won four of the top five places. This victory, and the creation of CAFENICA also contributed to the cooperatives' influence within larger Fair Trade policy debates, including a recent proposal to increase their minimum prices.

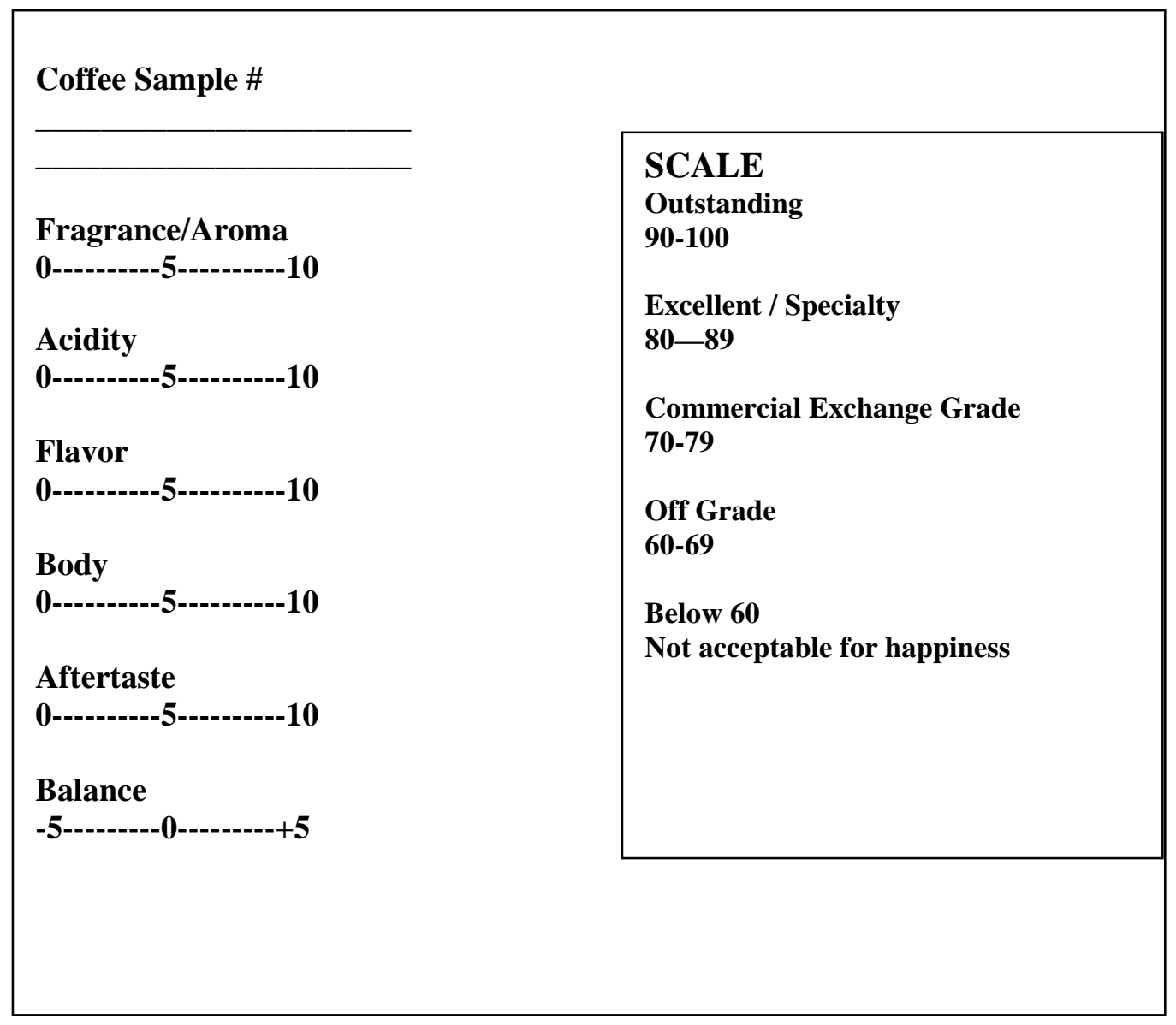

Figure 4: Early SCAA cupping evaluation form. Source: Adapted from Katzeff, $2001 \mathrm{~b}$.

Many of CAFENICA's Fair Trade allies still remember when the awards were announced in the exclusive Social Club in Matagalpa in 2004. The wealthy large estate owners, exporters, and eager NGO's like Techno Serve were there with other members of Nicaragua's Association de Café Especiales, fully expecting to walk away with most awards. The small-scale producers affiliated with the cooperatives were huddled together in back of the room, letting their paid general managers negotiate the clear class-based divisions. Yet by the end of the evening, they walked away with the top awards. Merling Preza, PRODECOOP's manager, also remembers this as one of the best moments in Nicaraguan cooperative history, "this is the time when we showed them that yes we can." Later in the press conference, she reminded all that producing quality coffee, just like working to improve people's quality of life, is the Responsibilidad de Todos (Everyone's Responsibility), she also re-stated the quality exchange proposal that Nicaragua smallholders offered industry and coffee consumers, stating that "This is the essence of a quality exchangequality coffee for the buyers in exchange for a higher quality of life and environmental quality within producer communities." 


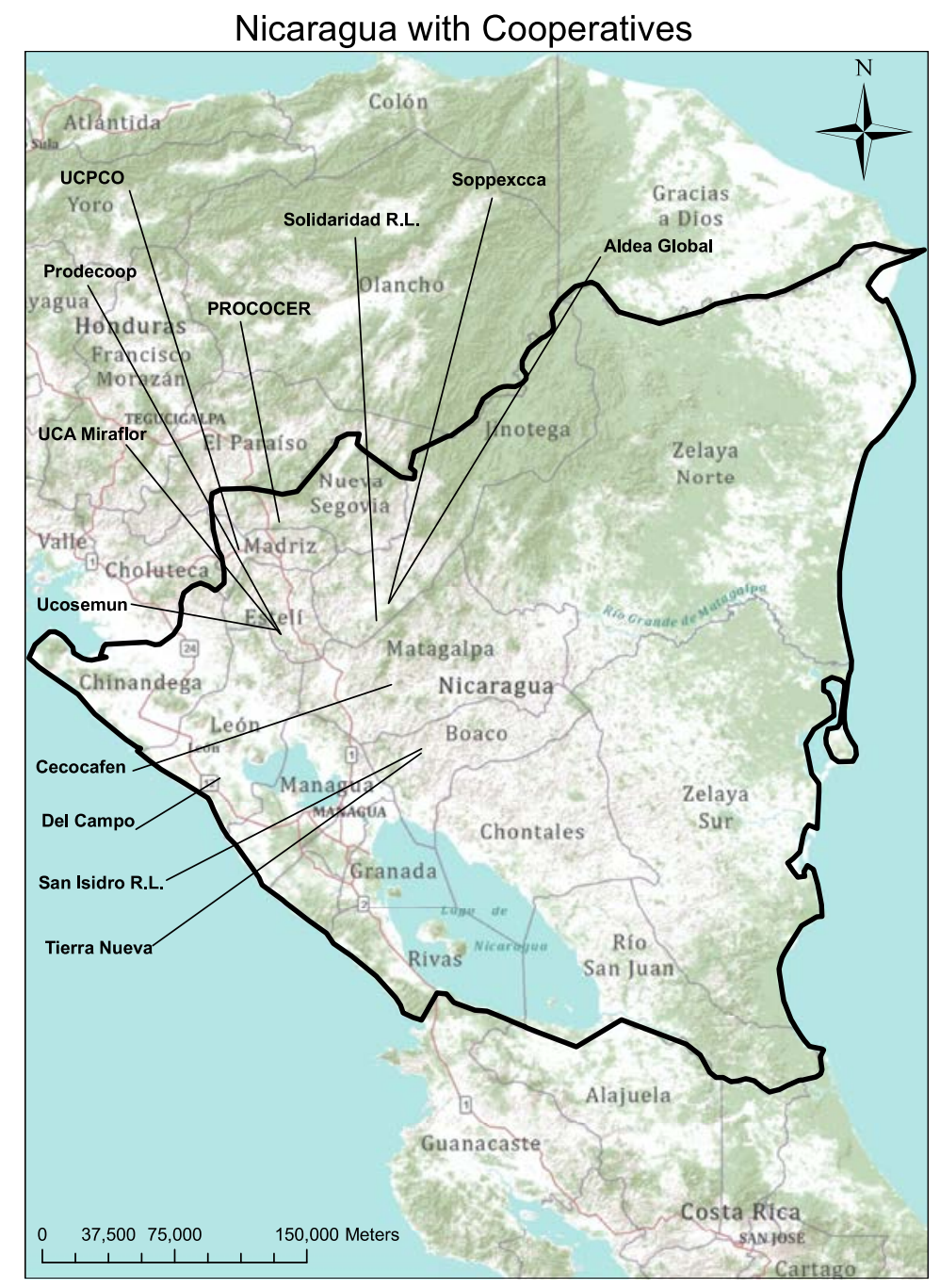

Figure 5: Map of small-scale coffee marketing cooperatives in Nicaragua affiliated with Cafenica. Source: Cafenica, 2008; Prepared by Antonia Gunner, Department of Environmental Studies and Sciences, Santa Clara University Nicaragua. Base map from: http://www.arcgis.com/home/item.html?id=f2498e3d0ff642bfb4b155828351ef0e.

The capacity of the cooperatives to organize smallholders and to defend their land titles has delivered benefits for their professional managers. Merling Preza is now on the board of directors for several of the most powerful Fair Trade movement oriented organizations, and CECOCAFEN's past president and manager during the project, Pedro Haslam, was elected to the Nicaragua's National Assembly in 2006, and as of 2012, he is the minister of the newly created Ministry of Family, Community, Cooperative and Associative Economies (Ministerio de Economía Familiar, Comunitaria, Cooperativa y Asociativa). The cooperative unions have also increased their productive capacity, professional staff, and social support programs. This empowerment process was uneven, even within the CAFENICA, and persistent tensions remain among the smaller and larger cooperatives within CAFENICA (Bacon 2006). Although the social and environmental qualities of coffee have often supported smallholder cooperatives, the costs of meeting the standards that focus on the physical and flavour-based attributes of the bean are very high and often lower the net revenues for farmers and cooperatives (Renard 2005; CLAC 2006). This project also contributed to several dynamic change processes within the specialty coffee industry. And yet, the outcomes among the smallholders were mixed. 


\begin{tabular}{|c|c|c|c|c|c|}
\hline Year & $\mathbf{2 0 0 2}$ & $\mathbf{2 0 0 3}$ & $\mathbf{2 0 0 4}$ & $\mathbf{2 0 0 5}$ & Total \\
\hline $\begin{array}{c}\text { Number coffee samples } \\
\text { identified as finalists from } \\
\text { an annual pool of 250-400 }\end{array}$ & 23 & 37 & 29 & 35 & 124 \\
\hline $\begin{array}{c}\text { Number of samples from } \\
\text { farms affiliated with } \\
\text { smallholder Fair Trade } \\
\text { cooperatives }\end{array}$ & 8 & 11 & 14 & 18 & 51 \\
\hline $\begin{array}{c}\text { Percentage finalists from } \\
\text { smallholder co-ops }\end{array}$ & $34.78 \%$ & $29.73 \%$ & $48.28 \%$ & $51.43 \%$ & $41.13 \%$ \\
\hline
\end{tabular}

Table 1: Nicaraguan Cup of Excellence scores, 2002-2005. Source: Twin 2005.

Changing smallholder livelihoods: Participatory research teams have conducted at least five studies involving more than 800 farmers in side-by-side comparisons to evaluate the impacts of participation in cooperatives and sales to Fair Trade markets in Northern Nicaragua (Bacon et al. 2008b; Bacon 2005a; Mendez et al. 2010; Arnould and Plastina 2005). Regardless of affiliation, the coffee revenue generated within most households in the country is insufficient to grant US\$1/day for the average of six people that live in a smallholder household (Bacon et al. 2008b). But the results from several past surveys reveal a more nuanced story, when farm households linked to Fair Trade cooperatives that have built these cupping labs are compared to similar households that are not affiliated to these cooperatives.

- Households linked to these cooperatives were more likely to have their school age children currently attending class, than those selling to conventional markets.

- Households connected to Fair Trade coops reported farm gate coffee prices that were 63\% higher than those reported by non-affiliated households in 2004.

- Farmers affiliated with Fair Trade cooperatives claimed access to more NGO-based social support networks than farmers that were not connected to these cooperatives (Bacon et al. 2008b).

Nonetheless, the evidence also shows that most small-scale farmers continue to navigate seasonal hunger, increased debt and persistent livelihood insecurities, suggesting that access to Fair Trade and organic coffee markets alone are insufficient to meet several of their important basic need goals.

\section{Resonance and revolutions: knowledge, power and praxis}

\section{Resonances}

This article resonates with others in this special section of the Journal of Political Ecology. Several of the same hybrids that enabled these sustainability innovations also surfaced in Ariane de Bremond's recounting of resurgent forests and rural communities in post-war El Salvador (de Bremond 2013). Moreover, like Phadke's article, I identify the new costs and potential shortcomings that can be associated with what is widely viewed as a positive alternative to business as usual (Fair Trade in this case and large dams in her case) (Phadke 2013). De Bremond and I both identify civil society's resistance to aspects of the Green Revolution, and in the coffee sector this is evident in the rise of social and environmental certification programs and the way that millions of smallholders have maintained their shade trees, older coffee plant varieties, and avoided becoming dependent on agrochemicals. This combination of older higher quality varieties and ecological conservation was part of the rapidly expanding specialty coffee market, titled "the Latte Revolution" by one author (Ponte 2002). Yet this industry-centered revolution is qualitatively different with regard to the stakes, popular struggle, level of risk, suffering, solidarity and occasional personal transformation that accompanied the 1979 Revolution in Nicaragua.

Although quality standards and the uneven power dynamics within tropical value chains continue to favor Northern retailers, roasters and traders, Nicaragua's coffee quality improvement project shows that an astute political ecology analysis, in fact a well-timed project financed by the United States Agency for International Development that united a progressive business leader with representative smallholder leaders, can find spaces for empowerment. The fragmentation and neoliberalization of the global coffee industry evidenced by the collapse of International Coffee Agreements facilitated still more revenue capture in Western countries (Talbot 2004). So far, higher quality standards have translated into more work, investments, and only slightly higher prices to tropical producers and smallholders. Paradoxically, this market fragmentation and the emergence of specialty coffee also contributed to the dramatic growth in Fair Trade sales in the USA. The partnership based model was promoted through Nicaragua's coffee cupping lab project, and through several versions of Fair Trade supported smallholder cooperative efforts to gain direct access to roasters and a fairer deal in increasingly uneven global markets. Cooperative leaders used these 
partnerships to secure several goals, such as rural smallholders land access, originally achieved through the Revolution that occurred when a popular uprising toppled the Somoza dictatorship and the Sandinista government promoted a series of agrarian reforms.

Emergent tensions: classic revolutions, Polanyian double movements, and the future of sustainable hybrids

In this article, I considered the connection between a Polanyian double movement to socially regulate the excesses of the free trade commodities market through the creation of the Fair Trade system, and the different ways this system connects to the politics of coffee production. I have explored the possibility that more direct producer-cooperative-roaster relations could be a starting point for a series of sustainability innovations and a renewed partnership with increased accountability and better results for Southern communities and landscapes (Rajan and Duncan 2013). I did this without forgetting the critical wing of political ecology which reminds us that a deeper agricultural and food-based imperialism is clearly the dominant trend in this recent post 1989 phase of liberalization and globalization and a recognition that Southern states will need to play a stronger role in efforts to negotiate a fairer deal for their citizens (Clapp and Fuchs 2009). Specifically, I addressed the transnational solidarity networks, hybrids, and state interventions that drove three interconnected sustainability innovations.

The 1979 Revolution and subsequent Sandinista government built agrarian social capital, "thickened a rural civil society", and cultivated the international solidarity efforts that influenced many small-scale coffee roasters, coffee drinkers and Western citizens in the process (Fox 1996; Perla 2008). Katzeff's political commitments combined intimate knowledge of coffee biochemical and taste characteristics gained from decades as a roaster, with an expanding business network. This proved an important contribution that was more than matched by the sophistication of smallholder cooperatives in Nicaragua. Beyond an elitist mark of distinction (Bourdieu 1984), the power of taste evaluation was quickly learned among rural cooperatives, opening up immediate business opportunities and a plethora of possibilities ranging from increased farmer participation in the art of coffee production to new forms of rural communication and experimentation (e.g. connecting agroecological farm management to flavors in the cup).

The cupping project prioritized the social ties of solidarity and craftsmanship, inserting the business development strategies that were oriented to the social economy into these relationships. In this way, it contributed to a relatively small Polanyian double movement in Nicaragua along the US coffee value chain. While important, the scale of this action is not commensurate with society-wide Polanyian double movements (Rajan and Duncan 2013). Rather than dismissing the case as insignificant, and highlighting the inability to translate these power shifts into substantial livelihood improvements among the thousands of farmers connected to these smallholder cooperatives, I propose we harvest the lessons learned from this experience and imagine the contents of a continuing praxis.

The sustainability innovations that emerged from this project were the construction of cupping labs within smallholder cooperatives, and the creation of a national association of smallholder cooperatives promoting artisan producers, sustainability and a vision of integrated quality (CAFENICA). As Figure 2 shows, the labs and cooperatives introduced a new dimension of performance into coffee value chains. Smallholders used this new generation of cooperatives and Fair Trade, and later the cupping labs, to compete for direct market access. Once in the market, they could more effectively peruse their community development goals. The social history of these innovations shows that they are much more than the market niche activities that some claim they are today.

The first hybrid in this story is the iterative nature-society relationships implicit in farming practice. If it were not for the farmers' labor, together with nature's ecological work, there would be no red coffee cherries to harvest and transform into that dark brew. Without the beans, there are no rural coffee cooperatives, Fair Trade certified marketplace, or coffee industry. No industry, no Starbucks, and no stories carried by these beans to distant places, and no energy to finish this article.

The second is a state-civil society hybrid that started in 1979 with the popular Revolution that toppled the Somoza dictatorship, continued in many programs promoted by the Sandinista government (though certainly not in all places given the growing personal economic interests, close-minded communist approach, and autocratic tendencies among a handful of individuals and ideologues within The Party). In the 1980s, the state supported what would later become more autonomous social movements and producer organizations (in the 1990s after the Sandinistas lost the election). Well beyond the contribution to this innovation, I argue that, like the "Revolutions of 1968", and Nicaragua's Revolution of 1979, "bequeathed ...a rethinking of the politics of the possible, and ....unleashed a long march through the institutions which have left an indelible mark on the politics of the contemporary era." (Watts 2001: 157). To borrow a term from David Harvey, they were "spaces of hope", some of which are still found today (Harvey 2000). The rethinking and the relationships inspired by this moment clearly enabled the three sustainability innovations (cooperatives, Fair Trade and cupping labs) discussed in this article.

There is a third business civil society hybrid. It is currently the most controversial, also enabled these sustainable innovations. The SCAA finds few parallels among industry associations today. It was able to mix civil society based sustainability politics in the USA with providing a platform for launching the Fair Trade certified coffee in the late 1990 s and early $21^{\text {st }}$ century. Along the way, it organized a symposium on human 
rights and third world economies in 1985. SCAA is part of Fair Trade itself, which began as a civil society based alternative trade partnership in the 1940s and 1950s. Yet, since a certification system was introduced in 1988 across many large corporations, Fair Trade labeling has increasingly become another niche marketing strategy (Bacon, et al., 2008). The increasing power of certification agencies and their pursuit of aggressive market-based growth, often at the expense of demands for social justice, has undermined the positions of many smallholder leaders and started to dilute the alternative trade and civil society and movement dimensions of the Fair Trade hybrid (Jaffee 2007; Bacon et al. 2008). This suggests a need to further explore the theoretical and empirical links between Polanyian double movements and more classically defined revolutionary politics.

\section{References}

Allen, P. 2004. Together at the table: sustainability and sustenance in the American agrifood system. University Park: Pennsylvania State University Press.

Arnould, E. and Plastina, A. 2005. Socio-economic impact study of trans fair intervention in the coffee marketing channel interim report: Nicaragua. Lincoln: University of Nebraska.

Bacon, C.M. 2006. Assessing fair trade coffee from the inside out in Nicaragua: an evaluation of TWIN/Cafedirect's work with the CECOCAFEN and PRODECOOP Cooperatives. London: Twin Trading.

Bacon, C.M. 2010a. Who decides what is fair in fair trade? The agri-environmental governance of standards, access, and price. The Journal of Peasant Studies 37(1): 111-147.

Bacon, C.M., V.E. Méndez, S.R. Gliessman, D. Goodman and J.A. Fox (eds). 2008a. Confronting the coffee crisis: fair trade, sustainable livelihoods and ecosystems in Mexico and Central America. Cambridge: MIT Press.

Bacon, C.M., V.E. Méndez, M.E.F. Gómez, D. Stuart, and S.R.D. Flores. 2008b. Are sustainable coffee certifications enough to secure farmer livelihoods? The Millenium Development Goals and Nicaragua's fair trade cooperatives. Globalizations 5(2): $259-274$.

Bebbington, A. 2000 Reencountering development: livelihood transitions and place transformations in the Andes. Annals of the Association of American Geographers 90(3): 495-520.

Belli, G. 1984. Amor Insurrecto (Insurgent Love). Managua: Nueva Nicaragua.

Bourdieu, P.1984. Distinction: a social critique of the judgment of taste. Cambridge, MA: Harvard University Press.

Brown, M.B. 1993. Fair trade: reform and realities in the international trading system. London: Zed Books.

Burbach, R. 2009. Revolutionary legacies in the 21st century. NACLA Report on the Americas 42(2): March/April.

CATO (Brink Lindsey). 2003. Grounds for complaint? Understanding the coffee crisis. Trade Briefing Paper 16, May 6.

CEPAL (Comisión Económica para América Latina y el Caribe). 2002. Centroamérica: el impacto de la caída de los precios del café. Mexico City: CEPAL.

CIPRES 2006. Pequeños y medianos productores agropecuarios: soberanía alimentaria y desarrollo agroindustrial. Managua: CIPRES (Centro para la Promoción La Investigación y el Desarrollo Rural y Social).

Cardenal, E. 2003. La revolución perdida. Managua: Ediciones Centroamericanas Anamá.

Chamorro, A. 2005. Fortaleciendo la integración e institucionalidad del movimiento cooperativo Nicaraguense. Managua: Centro para Economía Social.

Clapp, J., Fuchs, D.A. 2009. Corporate power in global agrifood governance. Cambridge, Mass: MIT Press.

Cory-Moran, B. 2008. Coffee buyer. Personal communication. Fort Bragg, CA: Thanksgiving Coffee Company.

Daviron, B. and Ponte, S. 2005. The coffee paradox: global markets, commodity trade, and the elusive promise of development. New York: Zed Books.

De Bremond, A. 2013. Regenerating conflicted landscapes in post-war El Salvador: livelihoods, land policy, and land use change in the Cinquera Forest. Journal of Political Ecology 20: 116-136.

Drucker, P. 1985. Innovation and entrepreneurship. New York: HarperCollins.

EFTA (European Fair Trade Association). 2003. The fair trade handbook: challenges of fair trade 20012003. Belgium: European Fair Trade Association.

Enríquez, L. 1991. Harvesting change labor and agrarian reform in Nicaragua, 1979-1990. Chapel Hill: University of North Carolina Press.

FLO (Fair Trade Labelling Organization). Standards in general. Bonn: FLO. 
FLO (Fair Trade Labelling Organizations) 2007. Fairtrade Labelling Organization's international annual report 2006/07. Bonn: FLO.

Fitter, R. and Kaplinsky, R. 2001. Who gains from product rents as the coffee market becomes more differentiated? A value chain analysis. IDS Bulletin 32(3): 69-82.

Fox, J. A. 1996. How does civil society thicken? The political construction of social capital in rural Mexico. World Development 24 (6): 1089-1103. PDF

Gilbert, C. 2011. International agreements for commodity price stabilisation: an assessment. OECD Food, Agriculture and Fisheries Working Papers No. 53. OECD Publishing.

Goodman, D. 2008. The international coffee crisis and review of the issues. in Bacon C.M., Méndez V.E., Gliessman S.R., Goodman D., and J. Fox (eds.) Confronting the coffee crisis: fair trade, sustainable livelihoods and ecosystems in Mexico and Central America. Boston: MIT Press.

Gould, J.L. 1990. Notes on peasant consciousness and revolutionary politics in Nicaragua 1955-1990. Radical History Review 48:65-87.

Guthman, J. 2007. The Polanyian way? Voluntary food labels as neoliberal governance. Antipode 39(3): 456-478.

Harvey, D. 2000. Spaces of hope. Berkeley CA: University of California Press.

Holt-Gimenez, E. 2009. From food crisis to food sovereignty: the challenge of social movements. Monthly Review 61(3):142-156

IADB et. al 2002. Managing the competitive transition of the coffee sector in Central America. Background report for the regional workshop, "The coffee crises and its impacts in Central America: situations and lines of action." Antigua: Inter-American Development Bank, US Agency for International Development, and the World Bank.

Jaffee, D. 2007. Brewing justice: fair trade coffee, sustainability, and survival. Berkeley: University of California Press.

Katzeff, P. 1998. Proposal to create a pilot project in Nicaragua, 1999-2002: the cupping laboratories for small producer cooperatives. Fort Bragg, California: Thanksgiving Coffee Company Inc.

Katzeff, P. 2001a. President of the Specialty Coffee Association of America. Nicaragua Personal communication.

Katzeff, P. 2001b Project Notes.

Kinzer, S. 1991. Blood of brothers: life and war in Nicaragua. New York: Putnam.

Lines, T. (Ed.) 2005. Agricultural commodities, trade and sustainable development. London: International Institute for Environment and Development and International Centre for Trade and Sustainable Development.

Liu, A. 2007. Investing in our shared future: SCAA's path to sustainability leads to UN's Millennium Development Goals. The SCAA Chronicle. (Jan./Feb.): 8-9.

Méndez, V. E., C.M. Bacon, M. Olson, S. Petchers, D. Herrador, C. Carranza, L. Trujillo, C. Guadarrama-Zugasti, A. Cordón and A. Mendoza. 2010. Effects of Fair Trade and organic certifications on small-scale coffee farmer households in Central America and Mexico. Renewable Agriculture and Food Systems 25(3): 236-251.

Mutersbaugh, T. 2004. Serve and certify: paradoxes of service work in organic-coffee certification. Environment and Planning D: Society and Space 22(4): 533-552.

Gresser, C. and S. Tickell. 2002. Mugged: poverty in your coffee cup. London: Oxfam International.

Paige, J.M. 1997. Coffee and power: revolution and the rise of democracy in Central America. Cambridge MA: Harvard University Press.

Peluso, N. L. and M.J. Watts (eds.) 2001. Violent environments. Ithaca: Cornell University Press.

Perla Jr., H. 2008. Si Nicaragua venció, El Salvador vencera'. Latin American Research Review 43(2): 13658.

Phadke, R. 2013. Water works in India. Journal of Political Ecology 20: 80-97.

Polanyi, K. 1944. The great transformation: the political and economic origins of our time. Boston: Beacon Press.

Ponte, S. 2002. The 'Latte Revolution'? Regulation, markets and consumption in the global coffee chain. World Development 30(7): 1099-1122.

Ponte, S. 2004. Standards and sustainability in the coffee sector: a global value chain approach. United Nations Conference on Trade and development and the International Institute for Sustainable Development.

Rajan S.R. and C.A.M. Duncan. 2013. Ecologies of Hope: environment, technology and habitation - case studies from the intervenient middle. Journal of Political Ecology 20:70-79.

Ramírez, S. 1999. Adiós muchachos: una memoria de la revolución Sandinista. México City: Aguila. 
Raynolds, L.T., D.L. Murray and A. Heller. 2007. Regulating sustainability in the coffee sector: a comparative analysis of third-party environmental and social certification initiatives. Agriculture and Human Values 24(2): 147-163.

Renard, M.C. 1999. Los intersticios de la globalización: un label (Max Havelaar) para los pequeños productores de café. Mexico City: Universidad Autónoma Chapingo, Embajada Real de los Paises Bajos, ISMAM, CEPCO.

Renard, M.C. 2005. Quality certification, regulation and power in fair trade. Journal of Rural Studies 21: 419-431.

Renard, M. C. 2010. The Mexican coffee crisis. Latin American Perspectives 37(2): 21-33.

Rocheleau, D.E., 2008. Political ecology in the key of policy: from chains of explanation to webs of relation. Geoforum 39(2): 716-727

Saldaña-Portillo, M.J. 2003. The revolutionary imagination in the Americas and the age of development. Durham: Duke University Press.

Seyfang, G. and A. Smith. 2007. Grassroots innovations for sustainable development: towards a new research and policy agenda. Environmental Politics 16(4): 584-603.

Talbot, J.M. 2004. Grounds for agreement: the political economy of the coffee commodity chain. Lanham: Rowman and Littlefield.

Tea and Coffee (no author). 2004. Coffee and tea reports from the front lines. Tea and Coffee Trade Online 178(1). http://www.teaandcoffee.net/0104/world.htm

Thanksgiving Coffee Company (TCC). 1987. The coffee for peace story. Fort Bragg: Thanksgiving Coffee Company.

Twin. 2005. Strengthening the commercial, financial management and business capacity of small coffee producers/exporters in Mexico and Nicaragua. London: Twin/ CFC/ICO/16. Exec. Summary

VanderHoff Boersma, F. 2009. The urgency and necessity of a different type of market: the perspective of producers organized within the fair trade market. Business Ethics 89(1(Supplement 1): 51-61.

Watkins, K., and P. Fowler. 2002. Rigged rules and double standards: trade, globalisation, and the fight against poverty. London: Oxfam.

Watts, M.J. and R. Peet. 2004. Liberating political ecology. In Watts, M.J. and R. Peet (eds.). Liberation ecologies. 2nd edn. London: Routledge. Pp. 1-30.

Watts, M.J. 2001. The Progress in Human Geography lecture: 1968 and all that ... Progress in Human Geography 25(2): 157-188.

Wilson, B.R., Conley, J.F., Harris, T.M., and F. Lafone. 2012. New terrains of taste: spatial analysis of price premiums for single origin coffees in Central America. Applied Geography 35(1-2): 499-507.

World Bank. 2005. Shocks and social protection: lessons from the Central American coffee crisis. Washington DC: World Bank.

\begin{abstract}
Nicaraguan smallholder cooperative leaders working in partnership with a California-based small-scale roasting company pioneered an alternative approach to confronting the post-1999 coffee crisis. They built coffee tasting laboratories and integrated grassroots organizing efforts to create a national smallholder cooperative association that dramatically improved the quality, consistency, and prices from of the coffee they exported. Cooperative leaders used this development project to gain a more significant share of political economic power in a domestic coffee industry historically dominated by colonial powers, and corporate and domestic elites. This alli.ance between the artisanal small-scale roasting companies and cooperative leaders also proved that smallholders selling into fair trade markets could consistently produce and export high quality coffee. This case study unfolds into Nicaragua's northern mountains, northern California's coastal cities and the commodity trade and solidarity networks that connect them. Beyond following the coffee bean from mountainside farmers, through artisan specialty coffee roasters, and into the hands of Bay Area coffee drinkers, the article recovers the history of political and technological revolutions and the transnational solidarity networks that contributed to sustainability innovations within the coffee value chain. Although the tangible benefits of fair trade coffee to farmers and landscapes have not lived up to the lofty proclamations of its advocates, farmers generally receive higher prices for their coffee and are frequently more secure in their land titles. This political ecology of coffee and solidarity suggests theoretical questions about the role of classic revolutions, and Polanyian double movements in the efforts to practice the alternative values and principles that motivate many of today's sustainability innovations.
\end{abstract}

Key words: Nicaragua, participatory action research, coffee cooperatives, sustainability, innovations. 


\section{Résumé}

Les dirigeants des coopératives de café au Nicaragua, a travaillé en partenariat avec une entreprise de torréfaction en Californie. Ensemble, ils ont lancé une autre approche pour faire face à la crise post-1999 de café. Ils ont construit des laboratoires de dégustation de café et de coopération intégrée à la base. Ils ont créé une association paysanne coopérative qui a considérablement amélioré la qualité, la cohérence et les prix du café qu'ils exportés. Les dirigeants des coopératives utilise ce projet de développement d'acquérir une part importante du pouvoir politico-économique dans un secteur du café historiquement dominé par les puissances coloniales, les entreprises, et les élites nationales. Cette alliance entre les artisans des petits entreprises de torréfaction et de dirigeants de coopératives ont également prouvé que les petits exploitants vendent leurs produits sur les marchés du commerce équitable pourrait toujours produire et exporter du café de haute qualité. Cette étude de cas se déroule dans les montagnes du nord du Nicaragua, les villes côtières du nord de la Californie et les réseaux commerciaux des produits de base et de la solidarité qui les relient. Il suit le grain de café auprès des agriculteurs à flanc de montagne, à travers les torréfacteurs de café de spécialité, et dans les mains de buveurs de café en Californie. Il récupère l'histoire des révolutions politiques et technologiques et les réseaux de solidarité transnationaux qui ont contribué à des innovations de développement durable au sein de la chaîne de valeur du café. Bien que les avantages tangibles de café issu du commerce équitable pour les agriculteurs et les paysages ne sont pas à la hauteur des aspirations élevées de ses partisans, les agriculteurs reçoivent des prix plus élevés pour leur café et sont souvent plus en sécurité dans leurs titres fonciers. Cette écologie politique du café et de la solidarité suggère des questions théoriques sur le rôle des révolutions classiques, et 'mouvements doubles' Polanyienne dans les efforts pour pratiquer les valeurs alternatives et des principes qui motivent un grand nombre d'innovations de développement durable d'aujourd'hui.

Mots clés: Nicaragua, la recherche-action participative, coopératives de café, la durabilité, l'innovation.

\section{Resumen}

Los líderes de cooperativas de pequeños propietarios nicaragüenses, trabajando conjuntamente con una pequeña compañía de torrefacción basada en California, fueron los primeros en aplicar una nueva forma de enfrentarse a la crisis del café posterior a 1999: construyeron laboratorios de cata de café e integraron los esfuerzos organizativos de comunidades de base para crear una asociación cooperativa nacional de pequeños propietarios que mejoró dramáticamente la calidad, la consistencia y los precios del café que exportaron. Los líderes de las cooperativas pusieron en marcha este proyecto para ganar una porción más significativa de poder político-económico en una industria cafetera históricamente dominada por los poderes coloniales, grandes empresas multinacionales y élites nacionales. Esta alianza entre pequeñas compañías artesanales de torrefacción y líderes de cooperativas también demostró que pequeños propietarios que venden en mercados de comercio justo pueden producir y exportar de manera consistente café de alta calidad. Este estudio de caso se desarrolla en las montañas del norte de Nicaragua, en ciudades costeras del norte de California y en las redes de comercio de mercancía y de solidaridad que las conectan. Más allá de seguir el grano de café desde los granjeros en las montañas, pasando por los artesanos especializados en la torrefacción, hasta llegar a los consumidores de café de Bay Area, el artículo recupera la historia de las revoluciones, tanto la política como la tecnológica, y las redes de solidaridad internacional que contribuyeron a las innovaciones en la sostenibilidad dentro de la cadena de valor del café. Esta política ecológica del café y la solidaridad provoca cuestionamientos teóricos sobre el papel de las revoluciones clásicas, dobles movimientos polanyanos en un esfuerzo por llevar a la práctica los valores alternativos y los principios que motivan numerosas innovaciones de sostenibilidad actuales.

Palabras clave: Nicaragua, la investigación-acción participativa, cooperativas de café, la sostenibilidad, la innovación. 